\title{
Mammalian diversity in West Java, Indonesia
}

\author{
TEGUH HUSODO ${ }^{1,2,3}$, SYA SYA SHANIDA ${ }^{3, \vartheta}$, PUPUT FEBRIANTO $^{2,3}$, M. PAHLA PUJIANTO ${ }^{3}$, \\ ERRI N. MEGANTARA ${ }^{1,2,3}$ \\ ${ }^{1}$ Department of Biology, Faculty of Mathematics and Natural Sciences, Universitas Padjadjaran. Jl. Raya Bandung-Sumedang Km 21, Jatinangor, \\ Sumedang 45363, West Java, Indonesia. \\ ${ }^{2}$ Program in Environmental Science, School of Graduates, Universitas Padjadjaran. J1. Sekeloa, Coblong, Bandung 40134, West Java, Indonesia. \\ ${ }^{3}$ Center of Environment and Sustainable Science, Directorate of Research, Community Services and Innovation, Universitas Padjadjaran. Jl. Raya \\ Jatinangor Km 21, Sumedang 45363, West Java, Indonesia. Tel./fax.: +62-22-7796412. `email: syasyashanida@gmail.com
}

Manuscript received: 4 April 2019. Revision accepted: 13 June 2019.

\begin{abstract}
Husodo T, Shanida SS, Febrianto P, Pujianto MP, Megantara EN. 2019. Mammalian diversity in West Java, Indonesia. Biodiversitas 20: 1846-1858. Protected forests in West Java are wider than conservation forests, whereas mammalian diversity in protected forests is as high as mammalian diversity in conservation forests. Mammals in protected forests are not protected by regional protection regulations, while anthropogenic factors in Java are quite high. This is possible that mammals who have high conservation status will experience local extinction. This study aims to determine (i) the composition of mammalian species and (ii) the species that are always found in studies of mammalian diversity in West Java. The study was conducted through a qualitative approach by combining several methods such as interview, camera trapping, sign survey, observation and transect, and collapsible traps. Mammalia in West Java found 54 species, 21 families, and nine orders with details of three species of Artiodactyla, 12 species of Carnivores, seven species of Chiroptera, one species of Dermoptera, one species of Euphotyphla, one species of Pholidota, five species of Primates, 21 species of Rodentia, and three species of Scandentia. The species that are always found in all study locations are nine species, including wild boar, Javan leopard, leopard cat, Javan mongoose, oriental small-clawed otter, Asian palm civet, grizzled leaf monkey, Javan langur, and Javan tree shrew. The results presented here may facilitate improvements in the mammalian diversity database, especially in the non-conservation area.
\end{abstract}

Keywords: Mammalia, protected species, West Java

\section{INTRODUCTION}

The diversity of mammals found in Indonesia is 720 species or more than $13 \%$ (Widjaja et al. 2014). Several of this species are found in West Java, one of the provinces in Indonesia that has a distribution of protected areas. The forest area as a habitat for most mammals tends to be concentrated in the Southern part of West Java which stretches from Sukabumi, Cianjur, Bandung, Garut, Sumedang, Tasikmalaya, Kuningan, and spreads to small parts in Purwakarta, and Subang (West Java Regional Environmental Management Agency 2008). Among these forest areas, Cisokan, Ciletuh, Kamojang, Darajat, and Gunung Salak are known to have various species of mammals based on previous studies.

Based on data from the West Java Forest Service, the forest area in West Java in 2017 is known to be conservation forest of $139,790.08$ hectares, while protected forest area of 274,830.62 hectares (Central Bureau of Statistic 2018). This shows that protected forests are more extensive than conservation forests. Most of the diversity and population ecology of medium and large mammals are targeted on National Park and sanctuaries of the country (Mohammed and Afework 2014), but outside of the protected areas records and conservation status of the different species of mammals are poorly known (Rabira et al. 2015).
Some study areas is located in the non-conservation forest areas in West Java, which are not protected by regional protection regulations. This unprotected area is inhabited by species of mammals that are protected both by national and international regulations. Besides that, the presence of endangered mammals in that unprotected area in West Java that has high anthropogenic factors will certainly increase the chances of local extinction. Many larger mammals are extinct on the island or have a highly fragmented distribution (Nijman 2013), putting an enormous pressure on biodiversity (Miettinen et al. 2011). Threats include forest decline, but also trade in wild animals for pets, traditional medicine or other economic uses (Rode-Margono et al. 2014). In the previous study, it was known that several species of mammals with high conservation status, such as the Javan leopard (Panthera pardus melas), Silvery gibbon (Hylobates moloch), Malayan pangolin (Manis javanica), and many more are exist in this areas.

Previous studies of biodiversity have been conducted in West Java, especially Ciletuh, Cisokan, Kamojang, Darajat, and Gunung Salak. This research was conducted to determine the latest condition of mammalian diversity by using a combination of several research methods, so the expected information related to the diversity of mammal species can be more comprehensive. 


\section{MATERIALS AND METHODS}

\section{Study area}

The study was conducted in five locations in West Java in 2017-2018, including Cisokan in West Bandung District, Ciletuh in Sukabumi District, Kamojang in Garut District, Darajat in Garut District, and Gunung Salak between Sukabumi and Bogor District, West Java. The study location can be seen in Figure 1.

West Java Province is divided into steep mountainous regions in the South with an altitude of more than 1500 masl, the area of the hillsides in the middle part of West Java with an altitude of 100-1500 masl, area in the North with an altitude of 0-10 masl. West Java is located between $5^{\circ} 50^{\prime}-7^{\circ} 50$ 'SL and $104^{\circ} 48^{\prime}-108^{\circ} 48$ 'EL. The area of West Java is $35,377.76 \mathrm{~km}^{2}$. The Northern part of West Java Province is bordered by the Java Sea, the Southern part is bordered by the Indian Ocean, the Western part is bordered by Banten Province and DKI Jakarta Province, and the Eastern part is bordered by Central Java Province (Central Bureau of Statistic 2018).

\section{Procedures}

The data collection technique in this study was conducted by qualitative methods by combining several methods, such as direct observation, camera trapping, collapsible trap, semi-structured interview, and sign survey (Husodo et al. 2019). The data were collected on 2017-
2018 in the Cisokan, Ciletuh Geopark (Ciemas SubDistrict), Darajat, Kamojang, and Gunung Salak.

\section{Semi-structured interview}

The semi-structured interview aims to identify potential sites as the habitat and existence of mammals in West Java. Interview was conducted with guidelines for interviews that had been made previously and could be developed during the interview. Informants were selected by the snowball sampling technique. The categorization of informants in this study was hunters, community elders, and buffalo herders, and farmers.

\section{Sign survey}

Sign surveys were conducted to find the existence of wild animals based on the existence that is left behind, such as feces, footprints, scratches on the ground or trees, hairs, and leftovers. Various signs of mammals existence that was found should be measured and were documented.

Indirect evidence is very useful when surveying animals such as carnivores that are naturally rare, elusive, found at low densities and difficult to capture repeatedly. So the presence of medium and large mammals were also been precisely indicated using indirect evidences, using sounds, spines, burrows and faecal droppings (Campos et al. 2013; Borges et al. 2014; Dereje et al. 2015).

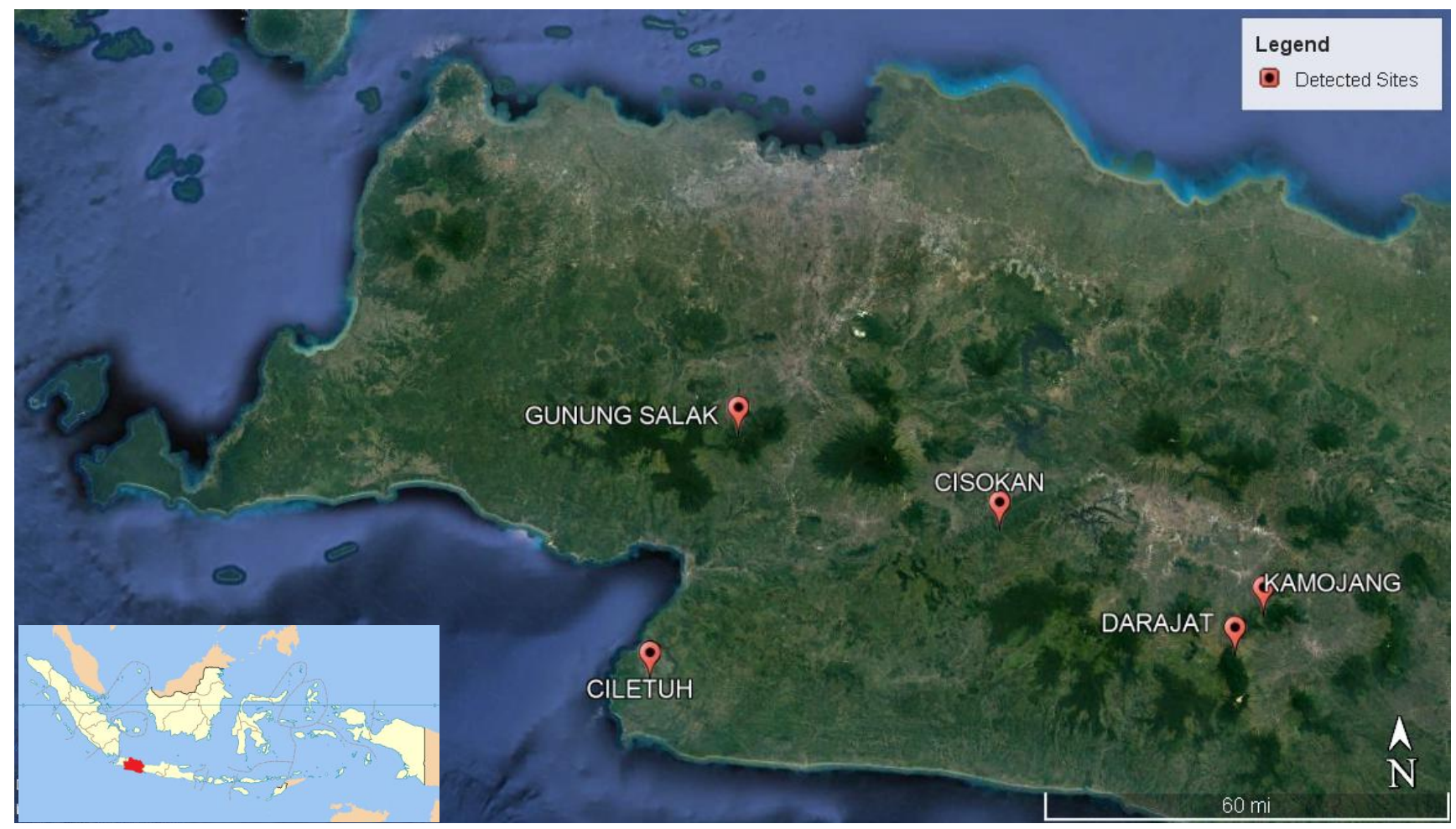

Figure 1. Study Areas in West Java, Indonesia; Cisokan (48 M 746030.02 m E $9231551.58 \mathrm{~m}$ S); Ciletuh (48 M $661159.73 \mathrm{~m}$ E 9198069.84 m S); Darajat (48 M 800811.68 m E 9200549.76 m S); Kamojang (48 M 808381.73 m E 9209763.04 m S); and Gunung Salak (48 M 683756.00 m E 9255797.00 m S). Source: Google Earth (2018) 


\section{Camera trapping}

Camera traps have been used to assess many ecological processes, including behaviour, occupancy, biodiversity, and density (Burton et al. 2015). The analytical methods used to estimate these processes vary based on the specific objectives, sampling designs and data recorded by ecologists (Keim et al. 2019). Camera-traps are widely used in South-East Asia for conservation and research particularly for inventorying ground-dwelling large mammal diversity within conservation landscapes (Phan et al. 2010; Moo et al. 2017) and estimating species density and abundance for conservation impact monitoring (Rayan and Mohamad 2009; Gray 2012; Gray and Prum 2012).

The installation of the camera was carried out to optimize the observation time for 24 hours. Installation period at least two weeks using 16 units of the camera trap. Determination of camera trap installation based on the location recommended by the local community, the result of sign survey, and previous research, as well as based on presence signs to get wildlife encounter from camera trap. Cameras were set between 30 and $50 \mathrm{~cm}$ above, and perpendicular to the ground. All photographs were checked manually and encounters with mammals identified to species by the author (Gray 2018). According to Sollman et al. (2013) that the main survey area's camera traps were set along active or abandoned logging roads, but the others were set randomly within the forest. We recorded the time of installation and retrieval of each camera and calculated the total duration of sampling (Debata and Kedar 2018).

\section{Direct observation}

Observations were made on mammals, including for bats, but no special method is used. Surveys in the sampled areas were performed twice a day, early in the morning (06.00 a.m. - 08.00 a.m.) and late in the afternoon (5.00 p.m. - 07.00 p.m.) when most mammals were more active in the study area (Meseret and Solomon, 2014; Dereje et al., 2015), and at night (07.00 p.m. - 10.00 p.m.). Signs of the mammal's existence that need to be considered include movement of tree branches and branches and sounds.

Care was taken by the observer not to disturb the animals (Dawd and Solomon 2013). During data collection, an observer walks on foot along each transect and directly count all the individuals sighted with their respective species using unaided eyes and binocular. Information like species, the number of individuals, location, habitat type, sex and age were recorded (Campose et al. 2013).

\section{Collapsible trap}

Collapsible traps are used for small mammals, such as collapsible Sherman trap and collapsible wire traps. The number of Sherman trap and wire trap is 15 traps with a total of 30 traps. Trap installation was conducted for two days at the determined sampling location. The bait used was peanut butter which had been mixed with oats and wrapped in gauze.

\section{Data analysis}

Qualitative data collected by observation and semistructured. The data were analyzed by cross-checking to get valid data, summarizing, synthesizing, and making narration with descriptive and evaluative analysis (Iskandar 2018). Animals caught during camera trap installation period and small mammals' trap and mammals track were identified using mammals' guidebook.

The analysis of conservation status of mammals species, referring to the National Regulation of the Republic of Indonesia (Regulation of the Minister of Environment and Forestry of the Republic of Indonesia No. P 106 on species of Protected Plants and Animals). In addition, it also refers to international regulations, namely the IUCN (International Union for Conservation of Nature) Red List and CITES (Convention on International Trade of Endangered Species).

\section{RESULTS AND DISCUSSION}

\section{Mammalian diversity}

Mammals in West Java, especially on Gunung Salak, Ciletuh, Cisokan, Kamojang, and Darajat were found in 54 species, 21 families, and nine orders with details of three species of Artiodactyla, 12 species of Carnivores, seven species of Chiroptera, one species of Dermoptera, one species of Euphotyphla, one species of Pholidota, five species of Primates, 21 species of Rodentia, and three species of Scandentia (Table 1). Camera trapping result of some mammals species are presented in Figure 2.

Based on the diversity of mammals in each study location, Ciletuh Geopark, especially Ciemas Subdistrict, was found as many as 24 species, while Cisokan and Gunung Salak were found 30 species, Kamojang was found 31 species, and Darajat was found 19 species. The species of mammals are obtained either through direct encounters or camera trap captures, interviews with the community, catches using small mammalian traps, and signs of wildlife such as footprints and feces.

Nine species were found in all study locations (Cisokan, Ciletuh, Kamojang, Darajat, and Gunung Salak), including wild boar (Sus scrofa), Javan leopard (Panthera pardus melas), leopard cat (Prionailurus bengalensis), Javan mongoose (Herpestes javanicus), oriental small-clawed otter (Aonyx cinerea), Asian palm civet (Paradoxurus hermaphroditus), grizzled leaf monkey (Presbytis comata), Javan langur (Trachypithecus auratus), and Javan tree shrew (Tupaia javanica).

Wild boar and Javan tree shrew can be assumed to be cosmopolitan mammals because they have the adaptability to various types of plant communities, so they are found in all study locations. Javan leopards can be found in all study locations due to the spread of prey, among them is the wild boar. Javan leopard has a high tolerance for environmental changes, so leopards do not only use the natural forest as a fulfillment of daily activities but other forests such as production forests (Pine forests). Leopard cat can be found in disturbed forests, production forests, or human modification lands, such as production forests, rice fields, gardens, and talun (mixed garden). This is because of the prey on these plant community types, such as snakes and mice. Acoording to Mohamed et al. (2009) that leopard 
cat's diet, mainly small rodents, might contribute to its tolerance of human-modified habitat. Asian palm civet is easily found at night and eats fruits from gardens and talun, such as sugar palm and coffee, so that daily activities are close to human activities. Rode-Margono et al. (2014) said that Asian palm civet was seen feeding once each on Jackfruit, Ficus. Civet faeces contained coffee beans, birds, small mammals, and invertebrates.

The existence of mammals from the Cercopithecidae family in all study locations shows that the forest as its habitat is still well preserved. Based on the species above (Table 1), the Order Chiroptera (bats) is found a little because, in the research procedure, there is no special method of the Order Chiroptera, but a survey is carried out so that the diversity of bats and the opportunity to meet bats at each time is small.

This study only reveals the findings of species in locations, does not reveal the distribution of individual species, especially in small and medium mammalian species. This is due to limited time and surveyor personnel. Based on Lim and $\mathrm{Ng}$ (2010) that small medium-sized forest-dwelling mammals are often nocturnal and solitary, therefore, difficult to study. With respect to the island of Java, few distribution surveys have covered small carnivores (many of which are nocturnal) or in general, the nocturnal mammals less popular amongst the general public. Many of these species' recent distribution data stem from chance sightings (Eaton et al. 2010; Moore 2011).

Several research articles revealed that in Cisokan, the Pangolin was estimated at 6-20 individuals. The estimation was undertaken based on the analysis of location, time, and individual morphology (Withaningsih et al. 2018). Leopard cat was estimated at 7-12 individuals, without information about gender (Shanida et al. 2018). The small size of leopard cats, identifying their sex, especially on the unambiguous identification of females, is much more difficult than on larger cat species, and thus sex could not be determined on many individuals (Mohamed et al. 2013). Javan leopard was estimated 1-2 individual (Shanida et al. 2018) that commonly found in natural forests (Husodo et al. 2019). Sunda porcupine was estimated 6-28 individuals (Mustikasari et al. 2019).

\section{Conservation status}

All species of mammals found listed by IUCN are partly protected by trade regulations of CITES and Regulation of the Minister of Environment and Forestry of the Republic of Indonesia (Table 1). Details of the protected species and found in West Java, including 12 protected species by national regulations, 54 protected species by IUCN (International Union for Conservation of Nature), and 20 protected species by CITES (Convention on International Trade in Endangered Species). The species listed in IUCN consist of CR (Critically Endangered): three species, EN (Endangered): two species, VU (Vulnerable): three species, NT (Near Threatened): three species, LC (Least Concern): 40 species, and DD (Data Deficient): three species. The species listed in CITES (Convention on International Trade in Endangered Species) consist of
Appendix I: four species, Appendix 2: 11 species, and Appendix III: five species.

Species that have CR status, such as Javan leopard can be found in all study locations (Cisokan, Ciletuh, Kamojang, Darajat, and Gunung Salak), but Javan slow lorises and Malayan pangolins are not found in Darajat. Species with EN status such as grizzled leaf monkey can be found in all study locations, but Silvery gibbon is only found in Cisokan, Ciletuh, and Gunung Salak. Species with VU status, such as the oriental small-clawed otter are only found in Ciletuh, Cisokan, and Kamojang. Binturong was only recorded in interview information on Gunung Salak, and Javan langur can be found in all study locations. Species with NT status, including large flying fox, blackstriped squirrel, and black giant squirrel.

Especially on Gunung Salak, which is near to the Gunung Halimun Salak National Park, it sets the species that are the priority in the study or called flagship species, including Silvery gibbon (Hylobates moloch) and Javan leopard (Panthera pardus melas). Silvery gibbon (Hylobates moloch) is a flagship species because its spread is limited to Java and Javan leopard (Panthera pardus melas) is a species that protected by government regulations and international regulations.

\section{Comparison of studies of mammalian diversity}

That is not all previous biodiversity studies have been conducted, such as in Ciletuh Geopark. The study of biodiversity in Ciletuh Geopark was only carried out in this study so that it became an opportunity for other researchers to conduct biodiversity studies as a comparison and complement the results of studies at Ciletuh Geopark. Based on Table 2, the total study about mammalian diversity from all locations was 18 times.

The most number of Order found, including 21 species of Rodentia, followed by 12 species of Carnivore, seven species of Chiroptera, five species of Primate, three species of Artiodactyla and Scandentia. The order Dermoptera, Eulipotyphla, and Pholidota as many as one species. Living mammals are estimated to have 4.000 species in the world; two-thirds of them are Rodentia (rodents). The order Rodentia is a major group of mammals (42\%) that can develop in various environments throughout the world with more than 2,050 recorded species (Baco 2011).

The number of species of the family, including Muridae as many as 11 species followed by Sciuridae as many as eight species. Others, in the fewest families, include Cervidae, Suidae, Tragulidae, Herpestestidae, Mephitidae, Prionodontidae, Cynochepalidae, Soricidae, Manidae, Hylobatidae, Hystricidae, and Leporidae as many as one species. Most of the study locations have many trees as habitat that is very suitable for the Sciuridae to live.

The mammalian diversity of each location and each year varied and fluctuating, including Cisokan ranging from 10-31 species, Ciletuh only 24 species, Darajat ranging from 18-21 species, Kamojang ranging from 19-26 species, and Gunung Salak ranging from 14-30 species. Based on all study locations, the species that always found throughout the study year (18 times) were three species, including wild boar (Sus scrofa), Javan leopard (Panthera 
pardus melas), and grizzled leaf monkey (Presbytis comata). These species are easily found in West Java. Habitat for these species can still fulfill their daily needs. In addition, mammals have a very dynamic movement and certain species have a wide range, which affects the encounter of mammal species in each study. The habitat that chosen by wild animals to live is the habitat that has the availability of food sources, water sources, shelter, and predators (Gunawan et al. 2016).

Javan leopard as endangered mammals can still be found in all study locations even found in each study from 2007. The existence of these Javan leopards is offset by an abundance of prey species, such as wild boar and grizzled leaf monkey as one of prey that also found in all study locations.

Indian Muntjak are the main prey for Javan leopard, so the presence of Indian Muntjak and Javan leopard will be directly proportional, the more abundant the Indian Muntjak population will be more and more Javan leopard. Based on the results of research in GHSNP (Gunung Halimun Salak National Park), the Indian Muntjak is the most mammal that commonly found, so the level of Indian Muntjak encounters with Javan leopards is greater than the other Javan leopards prey.
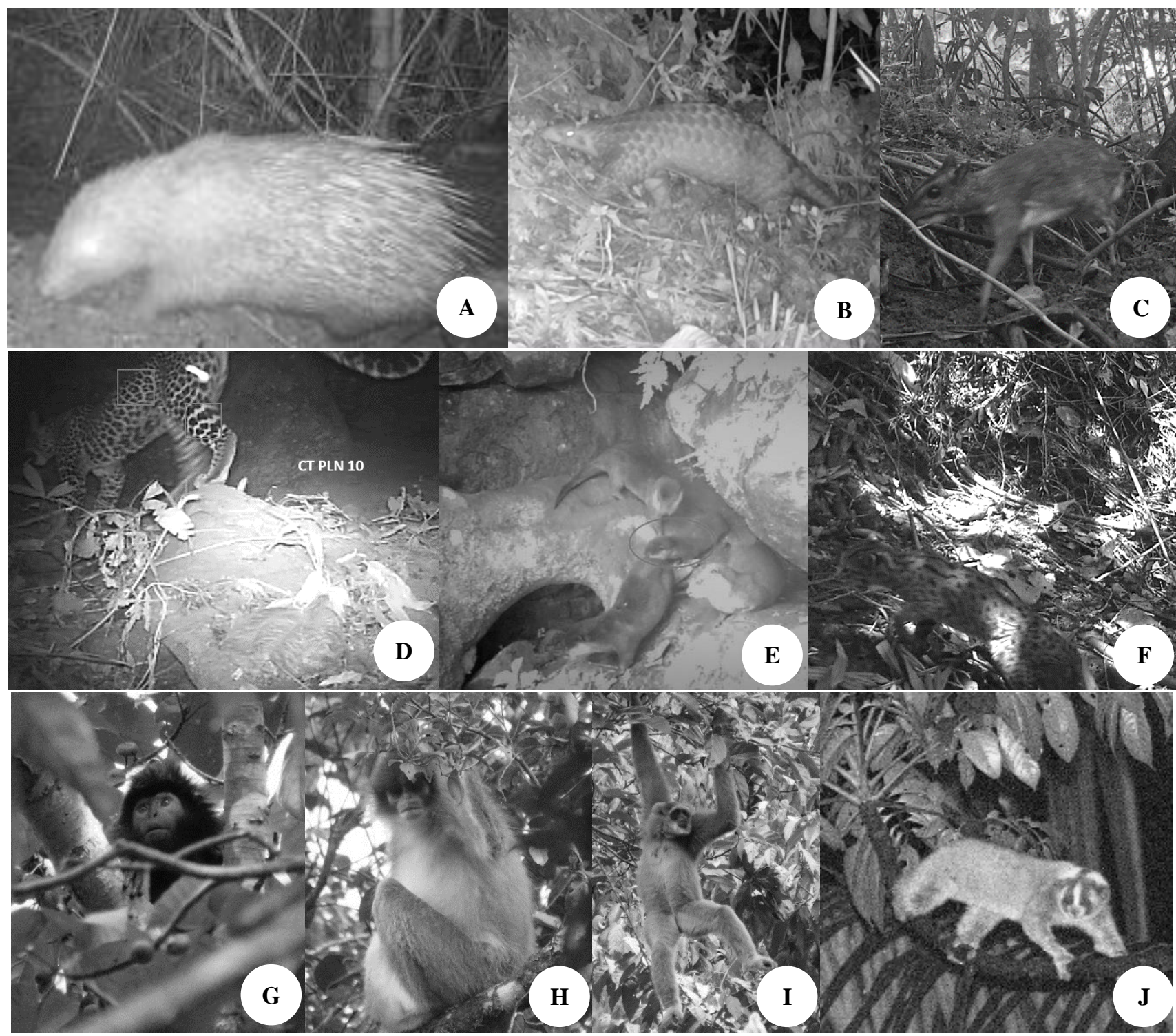

Figure 2. Mammals species in West Java, Indonesia; A. Sunda porcupine, B. Malayan pangolin, C. Lesser mouse-deer, D. Javan leopard, E. Oriental small-clawed otter, F. Leopard cat, G. Javan langur, H. Grizzled leaf monkey, I. Silvery gibbon, J. Javan slow loris. 
Table 1. Mammals species that found in West Java, Indonesia and its conservation status

\begin{tabular}{|c|c|c|c|c|c|c|c|c|c|c|}
\hline \multirow{2}{*}{ No } & \multirow{2}{*}{ Species } & \multirow{2}{*}{ English name } & \multicolumn{5}{|c|}{ Location } & \multicolumn{3}{|c|}{ Conservation Status } \\
\hline & & & $\overline{\text { CLT }}$ & CSK & KMJ & DRJ & GS & $\mathbf{R I}$ & IUCN & CITES \\
\hline \multicolumn{11}{|c|}{ ARTIODACTYLA } \\
\hline \multicolumn{11}{|c|}{ Cervidae } \\
\hline & Muntiacus muntjak (Zimmermann, 1780) & Indian Muntjac & & & $\mathrm{I}$ & & Fo & + & $\mathrm{LC}$ & \\
\hline \multicolumn{11}{|c|}{ Suidae } \\
\hline & Sus scrofa (Linnaeus, 1758) & Wild Boar & DE, CT, Fo & $\mathrm{CT}$ & $\mathrm{DE}$ & Fo & DE, Fo & & $\mathrm{LC}$ & \\
\hline \multicolumn{11}{|c|}{ Tragulidae } \\
\hline & Tragulus javanicus (Osbeck, 1765) & Lesser Mouse-Deer & $\mathrm{CT}, \mathrm{Fe}$ & $\mathrm{CT}, \mathrm{I}$ & & & Fo & + & $\mathrm{DD}$ & \\
\hline \multicolumn{11}{|c|}{ CARNIVORE } \\
\hline \multicolumn{11}{|c|}{ Felidae } \\
\hline & Panthera pardus melas (Cuvier, 1809) & Javan Leopard & $\mathrm{CT}, \mathrm{Fo}$ & $\mathrm{CT}, \mathrm{I}$ & Fo, I & I & Fo & + & $\mathrm{CR}$ & I \\
\hline & Prionailurus bengalensis (Kerr, 1792) & Leopard Cat & $\mathrm{CT}, \mathrm{Fe}$ & DE, I & $\mathrm{DE}$ & $\mathrm{Fo}, \mathrm{Fe}$ & Fo & + & $\mathrm{LC}$ & II \\
\hline \multicolumn{11}{|c|}{ Herpestidae } \\
\hline & Herpestes javanicus (E. Geoffroy Saint-Hilaire, 1818) & Javan Mongoose & $\mathrm{Fe}$ & $\mathrm{CT}$ & I & I & I & & $\mathrm{LC}$ & III \\
\hline \multicolumn{11}{|c|}{ Mephitidae } \\
\hline & Mydaus javanensis (Desmarest, 1820) & Sunda Stink Badger & & & & & I & & $\mathrm{LC}$ & \\
\hline \multicolumn{11}{|c|}{ Mustelidae } \\
\hline & Aonyx cinerea (Illiger, 1815) & Oriental Small-clawed Otter & $\mathrm{Fe}$ & $\mathrm{CT}, \mathrm{I}$ & $\mathrm{I}$ & & & & VU & II \\
\hline & Martes flavigula (Boddaert, 1785) & Yellow-throated Marten & & & & & DE, Fo & & $\mathrm{LC}$ & III \\
\hline & Melogale orientalis (Horsfield, 1821) & Javan Ferret-badger & & & $\mathrm{I}$ & & I & & LC & \\
\hline \multicolumn{11}{|c|}{ Prionodontidae } \\
\hline & Prionodon linsang (Hardwicke, 1821) & Banded Linsang & & & & & $\mathrm{DE}$ & + & $\mathrm{LC}$ & II \\
\hline \multicolumn{11}{|c|}{ Viverridae } \\
\hline & Arctogalidia trivirgata (Gray, 1832) & Small-toothed Palm Civet & & & DE & & & & LC & \\
\hline & Arctictis binturong (Raffles, 1821) & Binturong & & & & & I & + & VU & III \\
\hline & Paradoxurus hermaphroditus (Pallas, 1777) & Asian Palm Civet & $\mathrm{DE}, \mathrm{Fe}$ & DE, CT & $\mathrm{DE}$ & $\mathrm{Fe}$ & $\mathrm{DE}$ & & LC & III \\
\hline & Viverricula indica (E. Geoffroy Saint-Hilaire, 1803) & Small Indian Civet & & $\mathrm{DE}$ & & & I & & $\mathrm{LC}$ & III \\
\hline \multicolumn{11}{|c|}{ CHIROPTERA } \\
\hline \multicolumn{11}{|c|}{ Pteropodidae } \\
\hline & Cynopterus sphinx (Vahl. 1797) & Greater Short-nosed Fruit Bat & & $\mathrm{DE}$ & & & & & $\mathrm{LC}$ & \\
\hline & Cynopterus brachyotis (Muller, 1838) & Lesser Short-nosed Fruit Bat & & $\mathrm{DE}$ & & & & & LC & \\
\hline & Hipposideros sp. (Gray, 1831) & Roundleaf Bat & & & & & $\mathrm{DE}$ & & $\mathrm{LC}$ & \\
\hline & Macroglossus minimus (E. Geoffroy, 1810) & Lesser long-tongued Fruit Bat & $\mathrm{DE}$ & & & & & & $\mathrm{LC}$ & \\
\hline & Macroglossus sobrinus (Andersen, 1911) & Greater Long-tongued Fruit Bat & & $\mathrm{DE}$ & & & & & $\mathrm{LC}$ & \\
\hline & Pteropus vampyrus (Linnaeus, 1758) & Large Flying Fox & & $\mathrm{DE}$ & & & & & NT & II \\
\hline & $\begin{array}{l}\text { Rousettus amplexicaudatus (E. Geoffroy Saint-Hilaire, } \\
\text { 1810) }\end{array}$ & Geoffroy's Rousette & $\mathrm{DE}$ & $\mathrm{DE}$ & & & $\mathrm{DE}$ & & $\mathrm{LC}$ & \\
\hline
\end{tabular}


DERMOPTERA

Cynochepalidae

Galeopterus variegatus (Audebert, 1799)

\section{EULIPOTYPHLA}

Soricidae

Suncus murinus (Linnaeus, 1758)

Asian House Shrew

\section{PHOLIDOTA}

Manidae

Manis javanica (Desmarest, 1822)

Malayan Pangolin

Fo

CT, I

Long-tailed Macaque

Cercopithecidae

Macaca fascicularis (Raffles, 1821)

Presbytis comata (Desmaret, 1822)

Trachypithecus auratus (E. Geoffroy, 1822)

Grizzled Leaf Monkey

Javan Langur

Hylobatidae

Hylobates moloch (Audebert, 1798)

Lorisidae

Nycticebus javanicus (E. Geoffroy, 1812)

Silvery Gibbon

Javan Slow Loris

$\mathrm{DE}$

$\mathrm{DE}$

DE

$\mathrm{DE}, \mathrm{I} \mathrm{DE} \quad \mathrm{DE} \quad \mathrm{DE}+\mathrm{EN}$

$\begin{array}{llll}\mathrm{DE}, \mathrm{I} & \mathrm{I} & \mathrm{DE} & \mathrm{DE}\end{array}$

DE

DE, I

DE

DE

DE

+ EN I

RODENTIA

Hystricidae

Hystrix javanica (Cuvier, 1823)

Leporidae

Lepus nigricollis (Cuvier, 1823)

Fo

CT

I

CT

$+\quad \mathrm{LC}$

Indian Hare

LC

Aeromys tephromelas (Gunther, 1873)

Callosciurus nigrovittatus (Horsfield, 1823)

Callosciurus notatus (Boddaert, 1785)

Black Flying Squirrel

Black-striped Squirrel

Plantain Squirrel

DE

$\begin{array}{ll}\text { DE } & \text { DE } \\ \text { CT } & \text { DE }\end{array}$

Three-striped Ground Squirre

Petaurista petaurista (Pallas, 1766)

Petinomys sp. (Thomas, 1908)

Red Giant Flying Squirre

CT

Small Flying Squirre

DE

Low's Squirrel

DE

$\mathrm{DE}$ 


\begin{tabular}{|c|c|c|c|c|c|c|c|c|c|}
\hline \multicolumn{10}{|l|}{ Muridae } \\
\hline Chiropodomys gliroides (Blyth, 1856) & Pencil-tailed Tree Mouse & $\mathrm{DE}$ & & I & $\mathrm{DE}$ & \multirow{5}{*}{$\mathrm{DE}$} & & \multicolumn{2}{|l|}{$\mathrm{LC}$} \\
\hline Hylomys suillus (Muller, 1840) & Short-tailed Gymnure & & & $\mathrm{T}, \mathrm{DE}$ & $\mathrm{DE}$ & & & \multicolumn{2}{|l|}{$\mathrm{LC}$} \\
\hline Maxomys surifer (Miller, 1900) & Red Spiny Rat & & & $\mathrm{T}$ & $\mathrm{DE}$ & & & \multicolumn{2}{|l|}{$\mathrm{LC}$} \\
\hline Niviventer lepturus (Jentink, 1879) & Narrow-tailed White-bellied Rat & & & $\mathrm{T}$ & & & & \multicolumn{2}{|l|}{$\mathrm{LC}$} \\
\hline Rattus argentiventer (Robinson and Kloss, 1916) & Rice-field Rat & & $\mathrm{T}$ & & & & & \multicolumn{2}{|l|}{$\mathrm{LC}$} \\
\hline Rattus exulans (Peale, 1848) & Polynesian Rat & $\mathrm{DE}$ & & $\mathrm{T}$ & DE, I & & & \multicolumn{2}{|l|}{$\mathrm{LC}$} \\
\hline Rattus tiomanicus jalorensis (Bonhote, 1903) & Malayan Field Rat & & & $\mathrm{T}$ & $\mathrm{DE}$ & & & \multicolumn{2}{|l|}{$\mathrm{LC}$} \\
\hline Rattus norvegicus (Berkenhout, 1769) & Brown Rat & & & & $\mathrm{DE}$ & & & \multicolumn{2}{|l|}{$\mathrm{LC}$} \\
\hline Rattus rattus (Linnaeus, 1758) & House Rat & & & $\mathrm{T}$ & & & & \multicolumn{2}{|l|}{$\mathrm{LC}$} \\
\hline Rattus tiomanicus sabae (Miller, 1900) & Malayan Wood Rat & & & $\mathrm{T}$ & $\mathrm{DE}$ & $\mathrm{T}$ & & \multicolumn{2}{|l|}{$\mathrm{LC}$} \\
\hline Suncus ater (Medway, 1965) & Black Shrew & & & $\mathrm{T}$ & I & & & \multicolumn{2}{|l|}{ DD } \\
\hline \multicolumn{10}{|l|}{ SCANDENTIA } \\
\hline \multicolumn{10}{|l|}{ Tupaiidae } \\
\hline Tupaia glis (Diard \& Duvaucel, 1820) & Common Tree Shrew & $\mathrm{DE}$ & & $\mathrm{DE}$ & $\mathrm{DE}$ & & & $\mathrm{LC}$ & II \\
\hline Tupaia javanica (Horsfield, 1822) & Javan Tree Shrew & $\mathrm{DE}$ & $\mathrm{DE}$ & $\mathrm{DE}$ & $\mathrm{DE}$ & $\mathrm{DE}$ & & $\mathrm{LC}$ & II \\
\hline Tupaia tana (Raffles, 1821) & Large Tree Shrew & $\mathrm{CT}$ & $\mathrm{CT}$ & & & & & $\mathrm{LC}$ & II \\
\hline TOTAL & & 24 & 30 & 31 & 19 & 30 & 12 & 54 & 20 \\
\hline
\end{tabular}

Sources: Primary Data (2017-2018), IUCN (2018), CITES (2018), and Regulation of the Minister of Environment and Forestry of the Republic of Indonesia (2018). Notes: Location = CLT: Ciletuh; CSK: Cisokan; KMJ: Kamojang; DRJ: Darajat; and GS: Gunung Salak. Data Type = DE: Direct Encounter, I: Interview, T: Trap, Fo: Footprint, Fe: Feces, CT: Camera Trap. Conservation status: RI = Regulation of the Minister of Environment and Forestry of the Republic of Indonesia No. P 106 on species of Protected Plants and Animals; IUCN = DD: Data Deficient; NT: Near Threatened; VU: Vulnerable; EN: Endangered; CR: Critically Endangered; CITES = I: Appendix I; Appendix II; Appendix III 
Table 2. Comparison of studies of mammalian diversity in each study location of West Java, Indonesia

\begin{tabular}{|c|c|c|c|c|c|c|c|c|c|c|c|c|c|c|c|c|c|c|c|}
\hline \multirow{2}{*}{ Species } & \multirow{2}{*}{ Local name } & \multicolumn{4}{|c|}{ CSK } & \multicolumn{3}{|c|}{ CLT } & \multicolumn{2}{|c|}{ DRJ } & \multirow[b]{2}{*}{18} & \multicolumn{4}{|c|}{ KMJ } & \multicolumn{4}{|c|}{ GS } \\
\hline & & 07 & 09 & 12 & 14 & 17 & 17 & 15 & 16 & 17 & & 14 & 15 & 16 & 17 & 07 & 14 & 15 & 18 \\
\hline \multicolumn{20}{|l|}{ ARTIODACTYLA } \\
\hline \multicolumn{20}{|l|}{ Cervidae } \\
\hline Muntiacus muntjak (Zimmermann, 1780) & Indian Muntjac & & & & & & & + & & & & + & + & & & + & + & + & + \\
\hline \multicolumn{20}{|l|}{ Suidae } \\
\hline $\begin{array}{l}\text { Sus scrofa (Linnaeus, 1758) } \\
\text { Tragulidae }\end{array}$ & \multicolumn{18}{|c|}{ Tragulidae } & + \\
\hline Tragulus javanicus (Osbeck, 1765) & Lesser Mouse-Deer & & + & + & + & + & + & & & & & & & & & + & + & + & + \\
\hline \multicolumn{20}{|l|}{ CARNIVORA } \\
\hline \multicolumn{20}{|l|}{ Felidae } \\
\hline Panthera pardus melas (Cuvier, 1809) & Javan Leopard & + & + & + & + & + & + & + & + & + & + & + & + & + & + & + & + & + & + \\
\hline Prionailurus bengalensis (Kerr, 1792) & Leopard Cat & & + & + & + & + & + & + & + & + & + & + & + & + & + & + & + & & + \\
\hline \multicolumn{20}{|l|}{ Herpestidae } \\
\hline Herpestes javanicus (E. Geoffroy Saint-Hilaire, 1818) & Javan Mongoose & & + & + & & + & + & & + & + & + & + & + & + & + & + & & & + \\
\hline \multicolumn{20}{|l|}{ Mephitidae } \\
\hline Mydaus javanensis (Desmarest, 1820) & Sunda Stink Badger & & & & & & & & & & & & & & & + & & & + \\
\hline \multicolumn{20}{|l|}{ Mustelidae } \\
\hline Aonyx cinerea (Illiger, 1815) & Oriental Small-clawed Otter & & + & + & + & + & + & & & & & + & + & + & + & & & & \\
\hline Martes flavigula (Boddaert, 1785) & Yellow-throated Marten & & & & & & & & & & & & & & & + & & + & + \\
\hline Melogale orientalis (Horsfield, 1821) & Javan Ferret-badger & & & & & & & & & & & & + & & + & & & + & + \\
\hline \multicolumn{20}{|l|}{ Prionodontidae } \\
\hline Prionodon linsang (Hardwicke, 1821) & Banded Linsang & & & & & & & + & + & + & & & & & & & & + & + \\
\hline \multicolumn{20}{|l|}{ Viverridae } \\
\hline Arctogalidia trivirgata (Gray, 1832) & Small-toothed Palm Civet & & & & & & & & & & & & & & + & & & & \\
\hline Arctictis binturong (Raffles, 1821) & Binturong & & + & + & & & & & & & & & & & & & & & + \\
\hline Paradoxurus hermaphroditus (Pallas, 1777) & Asian Palm Civet & & + & + & + & + & + & + & + & + & + & + & + & + & + & + & + & + & + \\
\hline Viverricula indica (E. Geoffroy Saint-Hilaire, 1803) & Small Indian Civet & & + & + & & + & & & & & & & & & & & & + & + \\
\hline
\end{tabular}




\section{CHIROPTERA}

Pteropodida

Cynopterus sphinx (Vahl. 1797)

Cynopterus brachyotis (Muller, 1838)

Cynopterus titthaecheilus (Temminck, 1825)

Hipposideros sp. (Gray, 1831)

Macroglossus minimus (E. Geoffroy, 1810)

Macroglossus sobrinus (Andersen, 1911)

Pteropus vampyrus (Linnaeus, 1758)

Lesser short-nosed Fruit Bat

Indonesian short-nosed fruit bat

Roundleaf Bat

Lesser long-tongued Fruit Bat

Greater Long-tongued Fruit Bat

Large Flying Fox

Rousettus amplexicaudatus (E. Geoffroy Saint-Hilaire, 1810) Geoffroy's Rousette

Eonycteris spelaea (Dobson, 1871)

Lesser Dawn Bat

Vespertilionidae

Glischropus javanus (Chasen, 1939)

Javan Thick-thumbed Bat

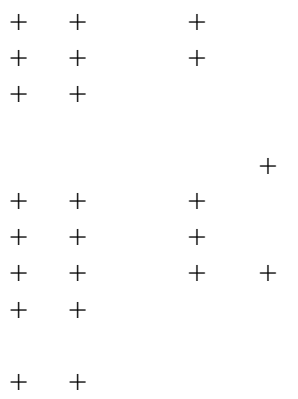

DERMOPTERA

Cynochepalidae

Galeopterus variegatus (Audebert, 1799) Sunda Flying Lemur

\section{EULIPOTYPHLA}

Soricidae

Suncus murinus (Linnaeus, 1758)

Asian House Shrew

Manis javanica (Desmarest, 1822) Malayan Pangolin

Manidae

\section{PRIMATE}

Cercopithecidae

Macaca fascicularis (Raffles, 1821)

Presbytis comata (Desmaret, 1822)

Trachypithecus auratus (E. Geoffroy, 1822)

Long-tailed Macaque

Grizzled Leaf Monkey

Javan Langur

\section{Hylobatidae}

Hylobates moloch (Audebert, 1798)

Silvery Gibbon

Lorisidae

Nycticebus javanicus (E. Geoffroy, 1812)

Javan Slow Loris

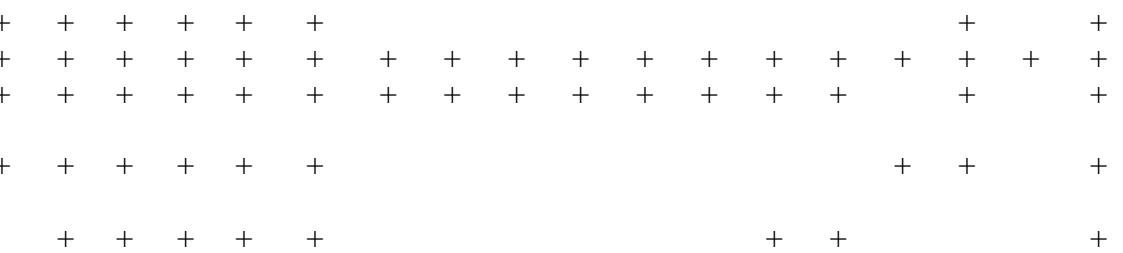




\section{RODENTIA}

Hystricidae

Hystrix javanica (Cuvier, 1823)

Hystrix brachyura (Linnaeus, 1758)

Leporidae

Lepus nigricollis (Cuvier, 1823)

Sciuridae

Aeromys tephromelas (Gunther, 1873)

Callosciurus nigrovittatus (Horsfield, 1823)

Callosciurus notatus (Boddaert, 1785)

Lariscus insignis (Cuvier, 1821)

Petaurista petaurista (Pallas, 1766)

Petinomys sp. (Thomas, 1908)

Ratufa bicolor (Sparman, 1778)

Sundasciurus lowii (Thomas, 1892)

Muridae

Chiropodomys gliroides (Blyth, 1856)

Hylomys suillus (Muller, 1840)

Maxomys surifer (Miller, 1900)

Niviventer lepturus (Jentink, 1879)

Rattus argentiventer (Robinson and Kloss, 1916)

Rattus exulans (Peale, 1848)

Rattus tiomanicus jalorensis (Bonhote, 1903)

Rattus norvegicus (Berkenhout, 1769)

Rattus rattus (Linnaeus, 1758)

Rattus tiomanicus sabae (Miller, 1900)

Suncus ater (Medway, 1965)
Sunda Porcupine

Malayan Porcupine

Indian Hare

Black Flying Squirre

Black-striped Squirre

Plantain Squirrel

Three-striped Ground Squirrel

Red Giant Flying Squirrel

Small Flying Squirre

Black Giant Squirrel

Low's Squirrel

Pencil-tailed Tree Mouse

Short-tailed Gymnure

Red Spiny Rat

Narrow-tailed White-bellied Rat

Rice-field Rat

Polynesian Rat

Malayan Field Rat

Brown Rat

House Rat

Black Shrew

Common Tree Shrew

Javan Tree Shrew

Mountain Tree Shrew

Large Tree Shrew
Malayan Wood Rat

$+$

(n)
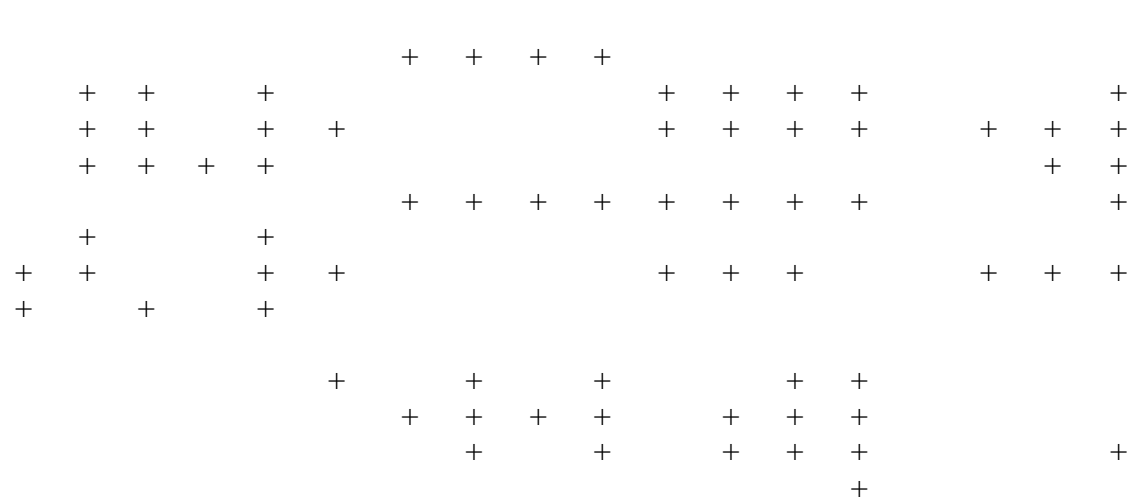

$++++\quad+\quad+\quad+\quad+$

Tupaia glis (Diard \& Duvaucel, 1820)

Tupaia javanica (Horsfield, 1822)

Tupaia montana (Thomas, 1892)

Tupaia tana (Raffles, 1821)

TOTAL

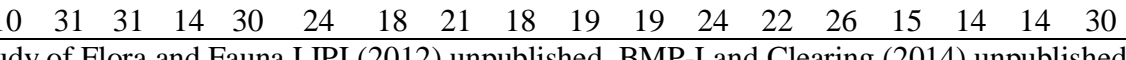

Note: Cisokan (CSK): Study of ANDAL (2007) unpublished, Rahmat (2009) unpublished, Thematic study of Flora Primary data (2017). Ciletuh (CLT): Primary data (2017). Darajat (DRJ): Primary data (2015), Primary data (2016), Primary data (2017), Primary data (2018). Gunung Salak (GS): Ario (2007), GHSNP-Indonesia Power (2014) unpublished, GHSNP-Indonesia Power (2015), Primary data (2018) 


\section{Cisokan}

The species that always found in each study are seven species, including wild boar (Sus scrofa), Javan leopard (Panthera pardus melas), Malayan pangolin (Manis javanica), long-tailed macaque (Macaca fascicularis), grizzled leaf monkey (Presbytis comata), Javan langur (Trachypithecus auratus), and Silvery gibbon (Hylobates moloch). The only species found in this study was large tree shrew (Tupaia tana). Species found in the previous years, but not found in this study, including Malayan porcupine (Hystrix brachyura), lesser dawn bat (Eonycteris spelaea), common thick-thumbed bat (Glischropus javanus), and Indonesian short-nosed fruit bat (Cynopterus titthaecheilus).

\section{Darajat}

The species that always found in each study are 13 species, including wild boar (Sus scrofa), Javan leopard (Panthera pardus melas), leopard cat (Prionailurus bengalensis), Asian palm civet (Paradoxurus hermaphroditus), grizzled leaf monkey (Presbytis comata), Javan langur (Trachypithecus auratus), black flying squirrel (Aeromys tephromelas), red giant flying squirrel (Petaurista petaurista), short-tailed Gymnure (Hylomys suillus), Polynesian Rat (Rattus exulans), Malayan field rat (Rattus tiomanicus jalorensis), brown rat (Rattus norvegicus), and Malaysian wood rat (Rattus tiomanicus sabae). Species found in previous years, but not found in this study were 5 species, including Indian Muntjak (Muntiacus muntjak), banded linsang (Prionodon linsang), sunda flying lemur (Galeopterus variegatus), Malayan porcupine (Hystrix brachyura), and large tree shrew (Tupaia tana).

The genus of Prionodon has a popular reputation for rarity and, thus, needing conservation attention, but there is no good evidence for this. At least for spotted linsang, recent records indicate a high adaptability to habitat degradation and fragmentation, and to hunting (Lau et al. 2010). According to the respondents, highly suitable habitats were lower and upper montane forest, and swamp forest (Duckworth et al. 2016). According to Cheyne et al. (2010) that the low encouter rate of banded lisang might reflect survey methods unsuitable for this species.

\section{Kamojang}

The species that always found in each study are 15 species, including wild boar (Sus scrofa), Javan leopard (Panthera pardus melas), leopard cat (Prionailurus bengalensis), Javan mongoose (Herpestes javanicus), oriental small-clawed otter (Aonyx cinerea), Asian palm civet (Paradoxurus hermaphroditus), grizzled leaf monkey (Presbytis comata), Javan langur (Trachypithecus auratus), Callosciurus nigrovittatus, Callosciurus notatus, Petaurista petaurista, Rattus exulans, Rattus tiomanicus sabae, Tupaia glis, and Tupaia montana. The species found only in this study were four species, including Arctogalidia trivirgata, Suncus murinus, Niviventer lepturus, and Rattus tiomanicus jalorensis. Species found in previous years, but not found in this study were 4 species, including Muntiacus muntjak, Galeopterus variegatus, Manis javanica, and Hystrix javanica.

\section{Gunung Salak}

The species that always found in each study are six species, including Muntiacus muntjak, Sus scrofa, Tragulus javanicus, Panthera pardus melas, Paradoxurus hermaphroditus, and Presbytis comata. The species found only in this study were eight species, including Arctictis binturong, Hipposideros sp., Rousettus amplexicaudatus, Manis javanica, Nycticebus javanicus, Callosciurus nigrovittatus, Petaurista petaurista, and Maxomys surifer. Species found in previous years, but not found in this study were two species, including Rattus tiomanicus jalorensis and Tupaia montana.

In conclusion, mammalia in West Java found 54 species, 21 families, and nine orders with details of three species of Artiodactyla, 12 species of Carnivores, seven species of Chiroptera, one species of Dermoptera, one species of Euphotyphla, one species of Pholidota, five species of Primates, 21 species of Rodentia, and three species of Scandentia. The species that are always found in all study locations are nine species, including wild boar, Javan leopard, leopard cat, Javan mongoose, oriental smallclawed otter, Asian palm civet, grizzled leaf monkey, Javan langur, and Javan tree shrew.

\section{ACKNOWLEDGMENTS}

Acknowledgments were given to Centre Environment Sustainability Science (CESS) Padjadjaran University, Indonesia Prof. Erri Noviar Megantara Academic Leadership Grant Padjadjaran University 2017-2018 who have supported this research, and the research team.

\section{REFERENCES}

Baco D. 2011. Control of rats in rice plants through an ecological approach. Dev Agric Innov 4 (1): 47-62.

Borges HLM, Calouro AM, Botelho ALM, Silveira M (2014). Diversity and habitat preference of medium and large sized mammals in an urban forest fragment of south western Amazon. Iheri Serie Zool. 104 (2): 168-174

Campos FS, Large ARB, Ribeirop PHP (2013). Diversity of medium and large sized mammals in a Cerrado fragment of central Brazil. J Threat Taxa 5 (15): 4994-5001

Central Bureau of Statistic. 2018. West Java Province in Figures. Central Bureau of Statistic of West Java Province. Bandung. [Indonesian]

Cheyne SM, Husson SJ, Chadwick RJ, Macdonald DW. 2010. Diversity and activity of small carnivores of the Sabangau Peatswamp Forest, Indonesian Borneo. Small Carnivore Conservation 43: 1-7.

CITES. 2018. Checklist of CITES Species. http: //checklist.cites.org/\#/en. [September 12, 2018].

Dawd Y, Solomon Y. 2013. Mammals of the Mazie National Park, Southern Ethiopia. SINET: Eth J Sci 36 (1): 55-61.

Debata S and Kedar KS. 2018. Estimating mammalian diversity and relative abundance using camera traps in a tropical deciduous forest of Kuldiha Wildlife Sanctuary, eastern India. Mammal Stud 43: 4553.

Dereje N, Tsegaye G, Tadese H (2015). The Diversity, Distribution and Relative Abundance of Medium and Large-sized Mammals in Baroye Controlled Hunting Area, Illubabor Zone, Southwest Ethiopia. Inter. J Mol Evol Biodiv 5 (4): 1-9. 
Duckworth JW, Hiromitsu Samejima, Gono S, Andrew JH, Joanna R, Gabriella F, SM Cheyne, Matt H, Dave MA, Jedediah B, Anthony G, Yoshihiro N, Ramesh B, Jason Hon, Andrew JM, John M, DW Macdonald, Jerrold LB, Stephanie K-S, Andreas W. 2016. Predicted distribution of banded linsang Prionodon linsang (Mammalia: Carnivora: Prionodontidae) on Borneo. Raffles Bull Zool (Suppl.) 33: 71-77.

Eaton JA, Wüst R, Wirth R, Shepherd CR, Semiadi G, Hall J, Duckworth JW. 2010. Recent records of the Javan Small-toothed Palm Civet Arctogalidia (trivirgata) trilineata. Small Carniv Conserv 43: 16-22.

Fragoso JMV, Taal Levi, Luiz FBO, Jeffrey BL, Han Overman, Jane MR, Kirsten MS. 2016. Line transect surveys undetected terrestria mammals: implication for the sustainability of subsistence hunting. PLoS One 11: 4. DOI: 10.1371/journal.pone.0152659.

Gray TNE, Prum S. 2012. Leopard density in postconflict Cambodia: evidence from Spatially Explicit Capture Recapture. J Wildl Manag 76: $163-169$.

Gray TNE. 2012. Studying large mammals with imperfect detection: status and habitat preferences of wild cattle and large carnivores in eastern Cambodia. Biotropica 44: 531-536.

Gray TNE. 2018. Monitoring tropical forst ungulates using camera-trap data. J Zool. DOI: 10.1111/jzo.12547.

Gunawan H, Sugiarti, Anita R, Vivin S, Sihombing. 2016. The Diversity of faunal communities in the biodiversity park of Ciherang, Bogor, West Java, Indonesia. Biodiversitas 17 (2): 469-486.

Husodo T, Puput F, Erri NM, Sya Sya S, M Pahla P. 2019. Diversity of mammals in forest patches of Cisokan, Cianjur, West Java, Indonesia Biodiversitas 20 (5): 1281-1288.

Iskandar J, Iskandar BS. 2018. Ethnobiology, rice biodiversity and rice cultivation modernization: case study in Baduy and Naga community. J Biodjati 3 (1): 47-62.

IUCN. 2018. The IUCN Red List of Threatened Species. www.iucnredlist.org. [September 12, 2018]

Keim JL, Subhash RL, Philip D DeWitt, J Jeremy F, Noemie SJ. 2019 Estimating the intensity of use by interacting predators and prey using camera traps. J Anim Ecol. DOI: 10.1111/1365-2656.12960.

Lau MWN, Fellowes JR, and Chan BPL. 2010. Carnivores (mammalia: carnivora) in South China: a status review with notes on the commercial trade. Mammal Rev 42: 247-292.

Lim NT-L, Ng PK L. 2010. Population assessment methods for the Sunda Colugo Galeopterus variegatus (Mammalia: Dermoptera) in tropical forests and their viability in Singapore. Raffles Bull Zool 58: 157164.

Meseret C, Solomon Y (2014). Diversity of Medium and Large-sized Mammals in Borena-Sayint National Park, South Wollo, Ethiopia. Intl J Sci Bas Appl Res 15 (1): 95-106.

Miettinen J, Shi C, Liew SC. 2011. Deforestation rates in insular Southeast Asia between 2000 and 2010. Global Change Biol 17: 2261-2270

Mohamed A, Samejima H, and Wilting A. 2009. Record of five Bornean cat species from Deramakot Forest Reserve in Sabah, Malaysia. Cat News 51: 12-15

Mohamed A, Sollmann R, Bernard H, Ambu LN, Lagan P, Mannan S, Hofer H, Wilting A. 2013. Density and habitat use of the Leopard Ca (Prionailurus bengalensis) in three commercial forest reserves in Sabah, Malaysian Borneo. J Mammol 94 (1): 82-89.
Mohammed K, Afework B. 2014. Threats to mammals on fragmented habitats around Asella Town, central Ethiopia. Intl J Biodiver 2014: ID 903898. DOI: 10.1155/2014/903898.

Moo SSB, Froese, GZ, Gray TNE. 2017. First structured camera-trap surveys in Karen State, Myanmar, reveal high diversity of globally threatened mammals. Oryx. DOI: $10.1017 /$ S003060531600113.

Moore R. 2011. Sightings of Javan Small-toothed Palm Civets Arctogalidia trivirgata trilineata on Gunung Salak, West Java, Indonesia. Small Carniv Conserv 44: 38-39.

Mustikasari IA, Susanti W, Erri NM, Teguh H, Parikesit. 2019. Population and distribution of Sunda porcupine (Hystrix javanica $\mathrm{F}$. Cuvier, 1823) in designated area of Cisokan Hydropower, West Java, Indonesia. Biodiversitas 20 (3): 762-769.

Nijman V. 2013. One hundred years of solitude: effects of long-term forest fragmentation on the primate community of Java, Indonesia. In: Marsh LK, Chapman CA. (eds). Primates in fragments: complexity and resilience. Springer, New York.

Phan C, Prum S, Gray TNE. 2010. Recent camera-trap records of globally threatened species from the Eastern Plains Landscape, Cambodia. Cambodian J Nat Hist 2: 89-93.

Rabira G, Tsegaye G, Tadesse H. 2015. The diversity, abundance, and habitat association of medium and large-sized mammals of Dati Wolel National Park, Western Ethiopia. Intl J Biodiv Conserv 7 (2): 112-118.

Rayan DM, Mohamad SW. 2009. The importance of selectively logged forests for tiger Panthera tigris conservation: a population density estimate in Peninsular Malaysia. Oryx 43: 48-51.

Regulation of the Minister of Environment and Forestry of the Republic of Indonesia. 2018. Species of plants and animals protected. the Minister of Environment and Forestry of the Republic of Indonesia. Jakarta. [Indonesian]

Rode-Margono EJ, A Voskamp, D Spaan, JK Lehtinen, PD Roberts, V Nijman, KAI Nekaris. 2014. Records of small carnivores and of medium-sized nocturnal mammals on Java. Small Carniv Conserv 50: 1-11.

Shanida SS, Ruhyat P, Teguh H, Erri NM. 2018. Short Communication: Javan Leopard Cat (Prionailurus bengalensis javanensis Desmarest, 1816) in the Cisokan non-conservation forest areas, Cianjur, West Java, Indonesia. Biodiversitas 19 (1): 37-41.

Shanida SS, Ruhyat P, Teguh H, Parikesit, Puput F, Erri NM. 2018. Short communication: the existence of Javan leopard (Panthera pardus melas Cuvier, 1809) in the non-conservation forest areas of Cisokan, Cianjur, West Java, Indonesia. Biodiversitas 19 (1): 42-46.

Sollmann R, Mohamed A, Samejima H, Wilting A. 2013. Risky business or simple solution - relative abundance indices from camera trapping. Biol Conserv 159: 405-412.

West Java Regional Environmental Management Agency. 2008. Environmental status in 2008. West Java Regional Environmental Management Agency. Bandung. [Indonesian]

Widjadja AE, Rahayuningsih Y, Rahajoe JS, Ubaidillah R, Maryanto I, Walujo EB, Semiadi G. 2014. Indonesia's current Biodiversity. LIPI Press. Jakarta. [Indonesian]

Withaningsih S, Noorahya F, Megantara EN, Parikesit, Husodo T. 2018. Nest existences and population of Pangolin (Manis javanica Desmarest, 1822) at the designated area of Cisokan Hydropower, West Java, Indonesia. Biodiversitas 19: 153-162. 